\title{
ENERGY INPUTS AND OUTPUTS IN A CHICKPEA PRODUCTION SYSTEM IN KURDISTAN, IRAN
}

\author{
PAYMAN SALAMI and HOJAT AHMADI \\ Department of Agricultural Machinery Engineering, Faculty of Agricultural Engineering and Technology, \\ University of Tehran, P.O. Box 4111, Karaj 31587-77871, Iran \\ Corresponding author: payman.salami@gmail.com, salami@ut.ac.ir
}

(Received 3 January, 2010; accepted 27 May, 2010)

\begin{abstract}
Chickpea (Cicer arietinum L.) is one of the most important grain legumes which traditionally cultivated in marginal areas and saline soils. In this study, chickpea production in Kurdistan, Iran and the energy equivalences of input used in production were investigated. The aims of this study were to determine the amount of inputoutput energy used in chickpea production, to investigate the efficiency of energy consumption, to make an economic analysis of chickpea production, and to establish a relation between energy inputs and yield. Data were collected through a survey using a face-to-face questionnaire. Diesel energy engrossed $37.9 \%$ of total energy, followed by chemical fertiliser $29.6 \%$ during production period. Energy efficiency was 1.04, and energy productivity was $0.07 \mathrm{~kg} \mathrm{MJ}^{-1}$. The profit-cost ratio of the farms was 1.17 . Calculated net return was $42.2 \$ \mathrm{ha}^{-1}$ in the investigated farms. The Cobb-Douglas function,, and the linear function, , were selected to establish the best fitness relations between the production and various energy inputs. Whereas the $\mathrm{R}$ squares in both models are close, but it has shown that the Cobb-Douglas model was better than linear model.
\end{abstract}

Key Words: Cicer arietinum, Cobb-Douglas function, energy efficiency, Iran

\section{RÉSUMÉ}

Le Chickpea (Cicer arietinum L.) est l'un de plus importantes graines de légumineuses traditionnellement cultivées dans les zones marginales et les sols salins. Dans cette étude, la production du chickpea, au Kurdistan, en Iran et les équivalences des énergies liées aux intrants utilisés dans la production ont été abordées. L'étude avaient pour objectifs de déterminer le montant des intrants et des produits de l'énergie utilisée dans la production du “chickpea,” d'examiner l'efficacité de la consommation d'énergie, de procéder à une analyse économique de la production du "chickpea”, et d'établir une relation entre les apports d'énergie et le rendement. Les données étaient collectées à travers une enquête utilisant une interview face -à -face. L'énergie à diesel occupait 37.9\% de l'énergie totale, suivi des engrais chimiques (29.6\%) durant la période de production. L'efficacité de l'énergie était de $1.04 \%$ et la productivité énergétique était de $0.07 \mathrm{~kg} \mathrm{MJ}^{-1}$. Le rapport profit-coût des fermes était de 1.17. Le bénéfice net calculé était de $42.2 \$$ ha $^{-1}$ dans les fermes soumises à l'enquête. La fonction de Cobb-Douglas et la fonction linéaire étaient sélectionnées pour établir les meilleures relations entre la production et les intrants énergétiques variés. Alors que les $\mathrm{R}^{2}$ étaient proches dans les deux modèles, il a été montré que le modèle de CobbDouglas était meilleure que le modèle linéaire.

Mots Clés: Cicer arietinum, fonction de Cobb-Douglas, efficacité de l’ energie, Iran 


\section{INTRODUCTION}

Chickpea (Cicer arietinum L.) is one of the most important grain legumes which is traditionally cultivated in marginal areas and saline soils (Rao et al., 2002). The agronomical importance of chickpea is based on its high protein content (25.328.9\%) in human and animal diet (Hulse, 1991). Chickpea cultivars, which are grown in Iran, include native (Desi) or Mediterranean (Kaboli) types (Sohrabi et al., 2008).

Energy in agriculture is important in terms of crop production and agro processing for value adding (Karimi et al., 2008).

The relation between agriculture and energy is very close. Agriculture itself is an energy user and energy supplier in the form of bio-energy. At present, productivity and profitability of agriculture depends on energy consumption (Alam et al., 2005).

Energy use in agriculture has developed in response to increasing populations, limited supply of arable land and desire for an increasing standard of living. In all societies, these factors have encouraged an increase in energy inputs to maximise, yields, minimise labour-intensive practices, or both (Esengun et al., 2007).

Energy in one form or another form is a crucial input to agricultural production. Continuously rising prices, increasing proportion of commercial energy in the total energy input to agriculture and the growing scarcity of commercial energy sources, such as fossil fuels, have necessitated the more efficient use of these sources for different crops (Singh et al., 1999).

Agriculture uses large quantities of locally available non-commercial energies, such as seed, manure and animate energy, and commercial energies directly and indirectly in the form of diesel, electricity, fertiliser, plant protection, chemicals, irrigation water, machinery, etc. Efficient use of these energies helps to achieve increased production and productivity and contribute to economy, profitability and competitiveness of agriculture sustainability to rural living (Singh et al., 2002).

The aim of this study was to determine the amount of input-output energy used in chickpea production, determine the efficiency of energy consumption and makes an economic analysis of chickpea production.

\section{MATERIALS AND METHODS}

The study involved 72 farmers growing chickpea in Kurdistan province, Iran. A face-to-face questionnaire was used in December 2008. The province is located in the west of Iran, within $34^{\circ}$

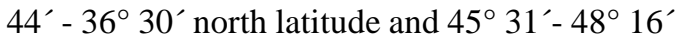
east longitude. The total area of the Kurdistan province is 2,820,300 ha. The mean annual rainfall of the province is 450 millimeters (Najafi, 1996).

For the growth and development, energy demand in agriculture can be divided into direct and indirect, and into renewable and nonrenewable energies (Alam et al., 2005). Energy efficiency of agricultural system was evaluated by the energy ratio between output and input. Human labour, machinery, diesel oil, fertiliser, pesticides, herbicides, fungicides, and seed amounts and yield values of chickpea crops were used to estimate the energy ratio. The amounts of input were calculated per hectare and then, these input data were multiplied with the coefficient of energy equivalent. Energy equivalents shown in Table 1 were used for estimation.

The Cobb-Douglas function and the linear function were used to establish the best fitness relations between the production and various energy inputs. The raw data were screened at the $95 \%$ confidence interval using the residual plot method to delete extreme observations.

Basic information on energy inputs and chickpea yields were entered into Excel and SPSS 17 spreadsheets. Based on the energy equivalents of the inputs and output (Table 1), the energy ratio (energy use efficiency) and energy productivity were calculated by using the equation 4 and 5 (Mandal et al., 2002; Singh et al., 1997).

Output - input ratio $=$ Energy output $\left(\mathrm{MJ}^{-1}\right) \ldots . . .(1)$ Energy input $\left(\mathrm{MJ}^{-1}\right)$

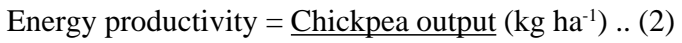
Energy input $\left(\mathrm{MJ}^{-1}\right)$ 
TABLE 1. Energy equivalent of inputs and outputs in agricultural production

\begin{tabular}{|c|c|c|c|}
\hline Particulars & Unit & Energy equivalent $\left(\mathrm{MJ}\right.$ unit $\left.^{-1}\right)$ & Source \\
\hline \multicolumn{4}{|l|}{ Inputs } \\
\hline Human labor & $\mathrm{h}$ & 1.96 & (Singh and Mittal, 1992; Erdal et al., 2007) \\
\hline Machinery & $\mathrm{kg}$ & & \\
\hline Tractor & & 138 & (Kitani, 1999) \\
\hline Plow & & 180 & (Kitani, 1999) \\
\hline Disk Harrow & & 149 & (Kitani, 1999) \\
\hline Fertiliser & & 129 & (Kitani, 1999) \\
\hline Diesel fuel & 1 & 56.31 & (Kizilaslan, 2009; Singh and Mittal, 1992; Erdal et al., 2007) \\
\hline Fertilisers & $\mathrm{kg}$ & & \\
\hline Nitrogen $(\mathrm{N})$ & & 78.1 & (Kitani, 1999) \\
\hline Chemicals & $\mathrm{kg}$ & & \\
\hline Pesticides & & 454 & (Kitani, 1999) \\
\hline Herbicides & & 290 & (Kitani, 1999) \\
\hline Fungicides & & 115 & (Kitani, 1999) \\
\hline 6. Seeds & $\mathrm{kg}$ & 14.7 & (Kitani, 1999) \\
\hline \multicolumn{4}{|l|}{ Outputs } \\
\hline Chickpea & $\mathrm{kg}$ & 14.7 & (Kitani, 1999) \\
\hline
\end{tabular}

Indirect energy included energy embodied in seeds, fertilisers, manure, chemicals, machinery, while direct energy covered human labour and diesel used in the chickpea production. Nonrenewable energy included diesel, chemical, fertilisers and machinery; and renewable energy consisted of human labour, seeds, and manure. Also, economic analysis of chickpea production was performed, and net profit and benefit-cost ratio were calculated. The net return was calculated by subtracting the total cost of production from the gross value of production per hectare. The benefit-cost ratio was calculated by dividing the gross value of production by the total cost of production per hectare (Demircan et al., 2006; Ozkan et al., 2004).

\section{RESULTS AND DISCUSSION}

Amounts of inputs and outputs in chickpea production for each item are illustrated in Table 2. Inputs, energy equivalences and ratio of inputs to output in the chickpea production are illustrated in Table 3. Total used energy in various farm operations during chickpea production was $5880 \mathrm{MJ}^{-1}$.

According to the evaluation of data in Table 2 , the average human labour required in the study area was $75.93 \mathrm{~h} \mathrm{ha}^{-1}$, and machine power was $5.87 \mathrm{~h} \mathrm{ha}^{-1}$. Almost $82.2 \%$ of total human labour was required for the harvesting operation, because in the study area the harvesting operation was done only by human labour without using machinery. About $46.7 \%$ of machine power was consumed for land preparation, $41.9 \%$ for other agricultural practices, and $11.4 \%$ for transporting of harvested chickpea. The distribution of the energy input ratios in the chickpea production are given in Figure 1.

Total energy consumed in various farm operations during chickpea production was 5880 $\mathrm{MJ} \mathrm{ha}^{-1}$. Diesel energy consumed 37.9\% of total energy, followed by chemical fertiliser $29.6 \%$ during production period. Diesel energy was mainly consumed for land preparation, other agricultural practices, and transportation. Total energy output was $6130 \mathrm{MJ} \mathrm{ha}^{-1}$, and average annual yield of investigated farms was $417 \mathrm{~kg}$ 
TABLE2. Amounts of inputs and output in chickpea production

\begin{tabular}{lc}
\hline Inputs & Quantity per unit area (ha) \\
\hline & \\
Labour (h) & 75.93 \\
Land preparation & 2.74 \\
Planting & 0.83 \\
Hoeing & 1.71 \\
Fertiliser application & 0.81 \\
Spraying & 1.23 \\
Harvesting & 62.44 \\
Threshing & 4.92 \\
Transporting & 1.25 \\
Machinery (h) & 5.87 \\
Land preparation & 2.74 \\
Hoeing & 1.71 \\
Spraying & 0.75 \\
Transporting & 0.67 \\
Diesel (L) & 39.61 \\
Land preparation & 19.85 \\
Hoeing & 10.16 \\
Spraying & 5.74 \\
Transporting & 3.86 \\
Fertilisers (kg) & 22.5 \\
Nitrogen (N) & 22.26 \\
Chemicals (kg) & 3.12 \\
Herbicides & 0.84 \\
Pesticides & 0.85 \\
Fungicides & 1.42 \\
Seeds & 43.21 \\
& \\
Output & \\
Chickpea yield (kg) & 417 \\
\hline & \\
& \\
& \\
&
\end{tabular}

TABLE3. Amount of inputs and output in chickpea production

\begin{tabular}{lccl}
\hline Inputs and output & $\begin{array}{c}\text { Quantity } \\
\text { (ha) }\end{array}$ & $\begin{array}{c}\text { Total } \\
\text { energy } \\
\text { equivalent } \\
\left(\mathrm{MJ} \mathrm{ha}^{-1}\right)\end{array}$ & $\begin{array}{l}\text { Perce- } \\
\text { ntage of } \\
\text { inputs }\end{array}$ \\
& \\
\end{tabular}

A. Inputs

1. Human labor (h) $\quad 75.93 \quad 145.5 \quad 2.5$

2. Machinery (h) $\quad 5.87 \quad 334.2 \quad 5.7$

3. Diesel fuel (L) $\quad 39.61 \quad 2230.6 \quad 37.9$

4. Chemical fertilisers $(\mathrm{kg})$

$\begin{array}{llll}\text { Nitrogen }(\mathrm{N}) & 22.26 & 1738.8 & 29.6\end{array}$

5. Chemicals $(\mathrm{kg})$

$\begin{array}{lrrr}\text { Herbicides } & 0.84 & 246.2 & 4.2 \\ \text { Pesticides } & 0.85 & 385.5 & 6.5 \\ \text { Fungicides } & 1.42 & 163.8 & 2.8 \\ & & & \\ \text { 6. Seeds (chickpea) }(\mathrm{kg}) & 43.21 & 635.2 & 10.8 \\ \text { Total energy input(MJ) } & - & 5880 & 100\end{array}$

\section{B. Output}

\begin{tabular}{lrrr} 
1. Chickpea $(\mathrm{kg})$ & 417 & 6130 & - \\
Total energy output(MJ) & - & 6130 & - \\
& & & \\
Output-input ratio & - & 1.04 & - \\
Energy productivity $\left(\mathrm{kg} \mathrm{MJ}^{-1}\right)$ & - & 0.07 & - \\
\hline
\end{tabular}

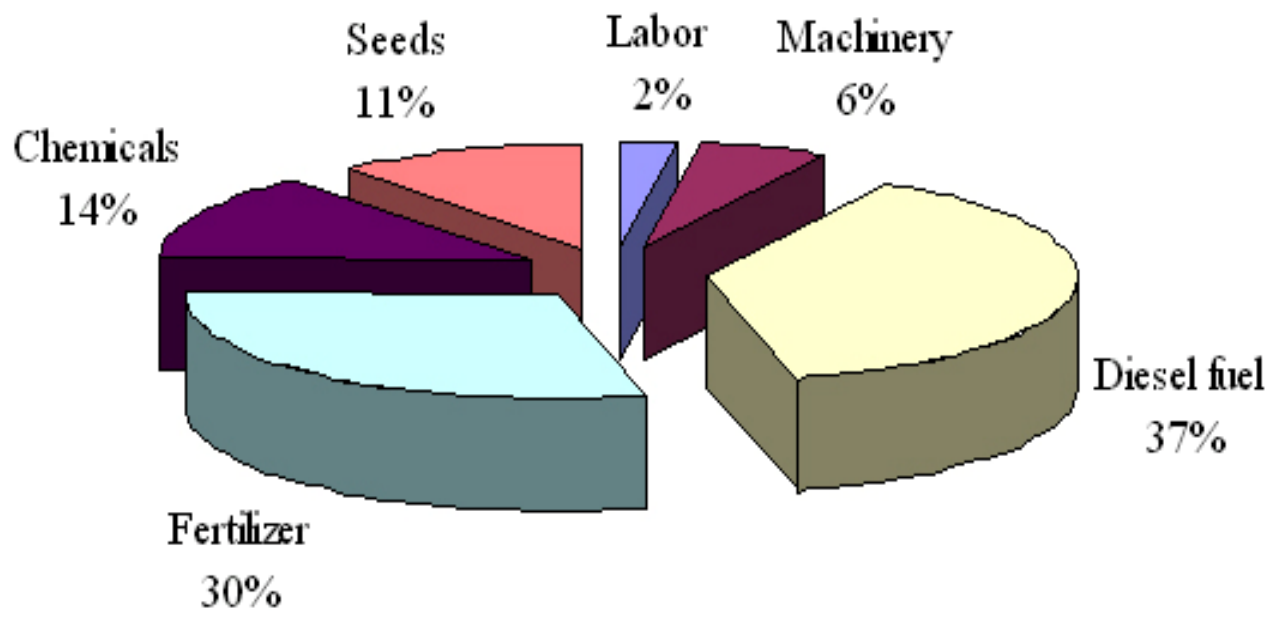

Figure 1. The distribution of energy input ratios in the chickpea production. 
ha $^{-1}$. Table 3 shows that human labour was the least demanding energy input for chickpea production, with $145.5 \mathrm{MJ} \mathrm{ha}^{-1}$ (only $2.5 \%$ of the total energy input). This was followed by fungicides by $163.8 \mathrm{MJ} \mathrm{ha}^{-1}(2.8 \%)$.

Salami et al. (2009) estimated the energy efficiency and energy productivity for red bean crop production in three land types in Kurdistan, Iran. The output-input ratio and energy productivity were 0.18 and $0.01 \mathrm{~kg}$ in the first land type, 0.42 and $0.03 \mathrm{~kg}$ in the second land type, and 044 and $0.03 \mathrm{~kg}$ in the third land type, respectively (Salami et al., 2009).

Singh et al. (1999) evaluated the energy efficiency in a study for three kinds of crops in Rajasthan, India. They estimated the energy efficiency for pearl millet, green gram, and wheat production. The output-input ratios were 4.8, 6.8, and 3.2, respectively (Singh et al., 2002).

In another study in Turkey, Esengun et al. (2002) evaluated the energy efficiency and energy productivity for dry apricot production in two land types. The output-input ratios and energy productivity were 1.24 and $0.24 \mathrm{~kg}$ in the first land type, and 1.31 and $0.25 \mathrm{~kg}$ in the second land type (Esengun et al., 2007).

Energy output-input ratio (energy efficiency) in this study was 1.04 , and energy productivity was $0.07 \mathrm{~kg} \mathrm{MJ}^{-1}$. This means that 0.07 of output obtained per unit energy.

Table 4 shows, the total consumed energy input could be classified as direct energy (40.4\%) and indirect energy (59.6\%), and also as

TABLE 4. Total energy input in the form of direct, indirect, renewable and non-renewable fo $r$ chickpea production (MJ ha $^{-1}$ )

\begin{tabular}{lcc}
\hline Form of energy & Quantity $\left(\mathrm{MJ} \mathrm{ha}^{-1}\right)$ & Percentage $^{\mathrm{a}}$ \\
\hline Direct energy $^{\mathrm{b}}$ & & \\
Indirect energy $^{\mathrm{c}}$ & 2376.2 & 40.4 \\
Renewable energy $^{\mathrm{d}}$ & 3503.8 & 59.6 \\
Non-renewable energye $^{\mathrm{e}}$ & 780.7 & 13.3 \\
Total energy input & 5099.3 & 86.7 \\
\hline
\end{tabular}

a Indicates percentage of energy input

${ }^{b}$ Includes human labour and diesel

' Includes seeds, fertilisers, manure, chemicals, and machinery

dIncludes human labor, seeds, and manure

${ }^{\mathrm{e}}$ Includes diesel, chemical, fertilisers, and machinery renewable energy $(13.3 \%)$ and non-renewable energy (86.7\%).

Data obtained from economic analysis are presented in Table 5. The profit/cost ratio, productivity, and Net profit in the chickpea production were $1.17,1.59$, and $46.2 \$$ ha $^{-1}$, respectively. The ratio of variable costs was higher than that of fixed costs. Variable costs were $51.4 \%$ of total production cost, and $48.6 \%$ of total costs.

Both the Cobb-Douglas and linear functions were used to establish the best fitness relations between the production and various energy inputs. These equations show the relation between direct energy, indirect energy, and the yield, and also show the relation between renewable energy, non-renewable energy, and the yield. Regression results for equation 3 and 4 are shown in Table 6 and 7, respectively.

Linear model

$\mathrm{Y}=47.068+0.245 \mathrm{E}_{1}+0.051 \mathrm{E}_{2}+0.091 \mathrm{E}_{4}+0.038 \mathrm{E}_{6}-0.265 \mathrm{E}_{7}, \mathrm{R}^{2}=0.891 \ldots$. (3)

Cobb-Douglas model

$\operatorname{In}(Y)=0.052+0.329 \operatorname{In}\left(E_{1}\right)+0.26 \operatorname{In}\left(E_{2}\right)+0.006 \operatorname{In}\left(E_{5}\right)+0.178 \operatorname{In}\left(E_{6}\right)-$

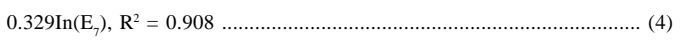
where, $Y=$ Yield $\left(\frac{\mathrm{kg}}{\mathrm{ha}}\right), \mathrm{E}_{1}=$ Seed energy $\left(\frac{\mathrm{MJ}}{\mathrm{ha}}\right), \mathrm{E}_{2}=$ Fertiliser energy $\left(\frac{\mathrm{MJ}}{\mathrm{ha}}\right), \mathrm{E}_{3}=$ Fungicide energy $\left(\frac{M J}{h a}\right), E_{4}=$ Herbicide energy $\left(\frac{M J}{h a}\right), E_{5}=$ Pesticide energy $\left(\frac{M J}{h a}\right), E_{6}=$ Diesel energy $\left(\frac{M J}{h a}\right), E_{7}=$ Machinery energy $\left(\frac{M J}{h a}\right)$, and $E_{8}=$ Human energy $\left(\frac{M J}{h a}\right)$

Whereas the R squares in both linear and CobbDouglas models are close, but it is clear that the

TABLE 5. Economic analysis of chickpea production

\begin{tabular}{lc}
\hline Cost and return items & Value \\
\hline Total production costs $\left(\$\right.$ ha $\left.^{-1}\right)$ & 261.9 \\
Fixed costs $\left(\$ \mathrm{ha}^{-1}\right)$ & 127.3 \\
Variable costs $\left(\$\right.$ ha $\left.^{-1}\right)$ & 134.6 \\
Gross production value $\left(\$ \text { ha }^{-1}\right)^{\mathrm{a}}$ & 308.1 \\
Benefitcost ratio & 1.17 \\
Productivity $\left(\mathrm{kg}^{-1}\right)^{\mathrm{b}}$ & 1.59 \\
Net return $\left(\$ \mathrm{ha}^{-1}\right)$ & 46.2 \\
\hline
\end{tabular}

${ }^{\mathrm{a}}$ Gross production value $=$ chickpea yield $\left(\mathrm{kg} \mathrm{ha}^{-1}\right)^{\star}$ price $\left(\$ \mathrm{~kg}^{-1}\right)$ ${ }^{\mathrm{b}}$ Productivity $\left(\mathrm{kg} \$^{-1}\right)=$ chickpea yield $\left(\mathrm{kg} \mathrm{ha}^{-1}\right) /$ Total production costs $\left(\$ h a^{-1}\right)$ 
TABLE 6. Regression results for linear model

\begin{tabular}{lrc}
\hline Exogenous variables $\left(\mathrm{MJ} \mathrm{ha}^{-1}\right)$ & Coefficient & t-ratio \\
\hline Constant & 47.068 & $0.451^{\mathrm{c}}$ \\
Seed energy & 0.245 & $5.052^{\mathrm{a}}$ \\
Fertiliser Energy & 0.051 & $2.607^{\mathrm{b}}$ \\
Herbicide Energy & 0.091 & $4.468^{\mathrm{a}}$ \\
Diesel Energy & 0.038 & $3.076^{\mathrm{a}}$ \\
Machinery Energy & -0.265 & $-2.913^{\mathrm{a}}$ \\
\hline
\end{tabular}

${ }^{a}$ Indicates significance at $1 \%$ level

${ }^{\mathrm{b}}$ Indicates significance at $5 \%$ level

${ }^{c}$ Indicates significance at $10 \%$ level

Cobb-Douglas model is better than linear model in this study. It also establishes the best fitness relations between the production and various energy inputs. The p-value in the linear model for fungicide energy, pesticide energy and human energy was higher than 0.05 and was excluded from the model. Also the p-value in the linear model for fungicide energy, herbicide energy, and human energy was higher than 0.05 and was excluded from the model.

According to the Table 6, the regression results of linear model revealed that the impact of energy inputs could be assessed positive on yield (except machinery energy). Seed energy had the highest impact (0.245) among the other inputs in chickpea production. This indicates that by increase in the energy obtained from seed input, the amount of output level improves in present condition. This impact was significant at $1 \%$ level, with respect to the assessed results; a $1 \%$ increase in the energy of seed input led to $0.245 \%$ increase in yield. The second important input was found as herbicide energy with the elasticity of 0.091 , followed by fertiliser energy and diesel fuel energy with the elasticity of 0.051 and 0.038 , respectively.

The regression results of Cobb-Douglas model is shown in Table 7. It unveiled that the impact of energy inputs could be assessed positive on yield (except machinery energy). Seed energy had the highest impact (0.329) among the other inputs in chickpea production. This shows that by increase in the energy obtained from seed input, the amount of output level improves in present condition. This impact was significant at $1 \%$ level, with respect to the assessed results; a
TABLE 7. Regression results for Cobb-Douglas model

\begin{tabular}{lcc}
\hline Exogenous variables $\left(\mathrm{MJ} \mathrm{ha}^{-1}\right)$ & Coefficient & t-ratio \\
\hline Constant & 0.052 & $0.038^{\mathrm{c}}$ \\
Seed energy & 0.329 & $4.384^{\mathrm{a}}$ \\
Fertiliser Energy & 0.260 & $3.233^{\mathrm{a}}$ \\
Pesticide Energy & 0.006 & $4.210^{\mathrm{a}}$ \\
Diesel Energy & 0.178 & $2.550^{\mathrm{b}}$ \\
Machinery Energy & -0.189 & $-2.490^{\mathrm{b}}$ \\
\hline
\end{tabular}

a Indicates significance at $1 \%$ level

${ }^{\mathrm{b}}$ Indicates significance at $5 \%$ level

${ }^{c}$ Indicates significance at $10 \%$ level

$1 \%$ increase in the energy of seed input led to $0.329 \%$ increase in yield. The second important input was found as fertiliser energy with the elasticity of 0.260 , followed by diesel fuel energy and pesticide energy with the elasticity of 0.178 and 0.006 , respectively.

\section{CONCLUSION}

Diesel energy monopolizes $37.9 \%$ of total energy followed by chemical fertiliser $29.6 \%$. Total energy consumption in various farm operations during chickpea production is $5880 \mathrm{MJ} \mathrm{ha}^{-1}$. Total energy output is $6130 \mathrm{MJ} \mathrm{ha}^{-1}$, and average annual yield is $417 \mathrm{~kg} \mathrm{ha}^{-1}$. Energy use efficiency is 1.04 , and energy productivity is determined as $0.07 \mathrm{~kg}$ $\mathrm{MJ}^{-1}$ in the study area. The human labor is the least demanding energy input for chickpea production with $145.5 \mathrm{MJ} \mathrm{ha}^{-1}$ (only $2.5 \%$ of the total energy input), followed by fungicides by 163.8 $\mathrm{MJ} \mathrm{ha}^{-1}$ (2.8\%). The total energy input consumption can be classified as direct energy (40.4\%) and indirect energy (59.6\%), and also renewable energy $(13.3 \%)$ and non-renewable energy (86.7\%). The economic analysis shows that the profit-cost ratio is 1.17. Calculated net return is $42.2 \$ \mathrm{ha}^{-1}$ in the investigated farms.

\section{REFERENCES}

Alam, M.S., Alam, M.R. and Islam, K.K. 2005. Energy flow in agriculture: Bangladesh. American Journal of Environmental Sciences 1 (3):213-220.

Demircan, V., Ekinci, K., Keener, H.M., Akbolat, D. and Ekinci, C. 2006. Energy and economic 
analysis of sweet cherry production in Turkey: a case study from Isparta province. Energy Conversion and Management 47:1761-9.

Erdal, G., Esengün, K., Erdal, H. and Gündüz, O. 2007. Energy use and economical analysis of sugar beet production in Tokat province of Turkey. Energy 32:35-41.

Esengun, K., Gündüz, O. and Erdal, G. 2007. Inputoutput energy analysis in dry apricot production of Turkey. Energy Conversion and Management 48:592-598.

Heady, E.O. and Dillon, J.L. 1961. Agricultural production functions. Ames, Iowa: Iowa State University Press. pp. 8-30.

Hulse, J.H. 1991. Nature composition and utilization of gran legumes. In: Uses of tropical legumes: Proceeding of a consultants meeting, 27-30 March 1989, ICRISAT Centre. ICRISAT, Patancheru, A.P.502324, India. pp. 11-27.

Karimi, M., Beheshti Tabar, I. and Khubbakht, G.M. 2008. Energy production in Iran's agronomy. American-Eurasian J.Agric. \& Environ.Sci. 4 (2):172-177.

Kitani, O. 1999. CIGR Handbook of Agricultural Engineering. Vol. V., Energy and Biomass Engineering. ASAE Publication, St Joseph, MI. 330pp.

Kizilaslan, H. 2009. Input-output energy analysis of cherries production in Tokat Province of Turkey. Applied Energy 86:1354-1358.

Mandal, K.G., Saha, K.P., Ghosh, P.K., Hati, K.M. and Bandyopadhyay, K.K. 2002. Bioenergy and economic analysis of soybean-based crop production systems in Central India. Biomass Bioenergy 23 (5):337-345.
Najafi, Y. 1996. Kurdistan Geography. (In Persian). Ozkan, B., Akcaoz, H. and Karadeniz, F. 2004. Energy requirement and economic analysis of citrus production in Turkey. Energy Conversion and Management 45:1821-30.

Rao, D.L.N., Giller, K.E., Yeo, A.R. and Flowers, T.J. 2002. The effects of salinity and sodicity upon nodulation and nitrigen fixation in chickpea (Cicer arietinum L.). Ann. Bot. 89 (5):563-570.

Salami, P., Keyhani, A. and Rafiee, S.H. 2009. The impact of farm size on energy use and profitability of red bean production in Iran: A case study in Kurdistan province. Nature and Science 7(9):95-104.

Singh, S. and Mittal, J.P. 1992. Energy in Production Agriculture. Mittal pub. New Delhi, India. 166pp.

Singh, M.K., Pal, S.K., Thakur, R. and Verma, U.N. 1997. Energy input-output relationship of cropping systems. Indian J. Agric. Sci. 67 (6): 262-266.

Singh, Sa., Singh, Su., Pannu, C.J.S. and Singh, J. 1999. Energy input and yield relations for wheat in different agro-climatic zones of the Punjab. Applied Energy 63:287-298.

Singh, H., Mishra, D. and Nahar, N.M. 2002. Energy use pattern in production agriculture of a typical village in arid zone, India-part I. Energy Conversion and Management 43: 2275-2286.

Sohrabi, Y., Heidari, G.. and Esmailpoor, B. 2008. Effect of salinity on growth and yield of Desi and Kabuli Chickpea cultivars. Pakistan Journal of Biological Sciences 11 (4):664-667. 